Article

\title{
Twenty-First Century Learning as a Radical Re-Thinking of Education in the Service of Life
}

\author{
Patrick G. Howard $(\mathbb{D}$
}

Department of Education, Cape Breton University, Sydney, NS B1P 6L2, Canada; Patrick_howard@cbu.ca

Received: 22 September 2018; Accepted: 24 October 2018; Published: 29 October 2018

\begin{abstract}
The education reforms called for in 21st century education initiatives have been characterized as radical. International efforts to reformulate education for 21st century teaching and learning are well-funded initiatives by coalitions including governments, not-for-profit organizations, and large corporations. This article is a critique of the emergence of 21st century learning showing that a preoccupation with competencies and skills can be interrogated for that to which 21st century learning gives voice, but also for that which it silences. The fundamental question of the purpose of education, or for what do we educate, is virtually absent in most discussions of 21st century learning. Finally, I offer an alternative curricular vision to the techno-optimistic belief in progress prevalent in the discourse of 21st century learning. In the call for radical reform, I propose another understanding of the word "radical," one that includes an ecocentric, life affirming understanding that roots education in a life code of value and in a living community of relations large enough to embrace the multidimensionality, the responsiveness, and responsibility at the heart of the pedagogical relation.
\end{abstract}

Keywords: twenty-first century learning; education reform; transformative education; pedagogical relations; life code of value

\section{Introduction}

Global efforts are underway to re-conceptualize K12 education for what is commonly known as 21st century teaching and learning. The preparation of students to meet emerging 21st century realties is foundational to these efforts. Standards, assessment, curriculum, instruction, professional development, and learning environments are shifting in the United States, Canada, Europe, Australia, New Zealand, and elsewhere despite many commonalities [1,2]. There are different approaches and varying levels of progress, as well as divergent views on how best to achieve the changes deemed to be necessary [3,4]. In Canada, provincial school curricula are being reformulated to include what are commonly referred to as 21 st century learning competencies [5-7]. The national and international shift to 21st century learning is due, in large part, to numerous reports and whitepapers published in the last decade, and well-organized, well-funded education initiatives launched by non-governmental and not-for-profit organizations [8]. Many of these initiatives were formed in partnership with large corporations with the stated mandate to shift education priorities to new education goals and to disrupt deeply embedded education practices initiated over a hundred years ago that are still foundational to current education practice [9-16].

In this article, I explore the emergence of 21st century learning and seek to define it as it has developed over the past two decades. I want interrogate it for what to 21st century education gives voice, but also for what it silences. I contend that 21st century learning is an education of preparation; it is future oriented and projects a functional purpose for education fused with the appeal that human ingenuity leading to technological innovation will extricate us from an ever-increasing list of social and economic ills. Finally, I offer an alternative curricular vision to the techno-optimism and 
belief in progress prevalent in the discourse of 21st century learning. An explicit discussion of the fundamental question of the purpose of education, or for what do we educate, is largely absent in discussions of 21st century learning. In the discourse of 21st century skills development, it is implicit, however, that education is designed to meet functional ends-to solve the world's problems, to answer the challenges of shifting workforce demands, and to develop good citizens. At the nexus of the foundational question of purpose and education writ large is the pedagogical relation, the generational leading out of the young, in the original meaning of educere, by a teacher who is responsible for living with children in an on-going project of renewal in a constantly shifting world. I propose a turn to a generative and life affirming understanding of education that roots the education enterprise firmly in the life process and in a living community of relations large enough to embrace the multidimensionality, the responsiveness, and responsibility at the heart of the pedagogical relation.

\section{21st Century Education as Skills and Competencies}

The term used to describe educational change happening today was originally called 21st century skills and it started to emerge as early as the 1980s when government, educators, and large corporations in the United States began publishing reports designed to inform education trends and to influence how students and workers could be better prepared for the demands of a rapidly emerging globalized, knowledge economy and digital society. The concept of 21st century skills as a focus for education reform originated with the publication of A Nation at Risk: The Imperative of Education Reform, the final report of the National Commission on Excellence in Education.

The report recommended instructional content and skills that were the forerunners of the 21st century competencies to emerge in the subsequent decades. The early skills and dispositions included: enthusiasm for learning, deep understanding, application of learning, inquiry, critical thinking, communication, technology, the world of computers and diverse learning across a broad range [17]. Additional efforts continued throughout the next two decades, both in North America and internationally [9], as governments, education policy makers, researchers, higher education institutions, multinational corporations, and private organizations published reports and formed coalitions such as the Partnership for 21st Century Skills (P21). By the 2000s, the idea that higher order thinking skills, abilities and dispositions, or deeper learning was necessary for success in an increasingly fast-paced, digitally connected, globalized world was firmly entrenched in education discourse. However, in the past decade there has been a noticeable shift in language of reform. Twenty first century skills have become 21st century learning. The move away from "skills" to "learning" began when the large, well-funded American organization, Partnership for 21st Century Skills became the Partnership for 21st Century Learning in 2002. However, as the coalition Canadian for 21st Century Teaching and Learning states, the mission of skills and competency development remains core to the work of these large coalitions [14].

A line can be drawn from the call for the creation of a Learning Society in A Nation at Risk [17] to current 21st century education projects such as Fullan and Langworthy's [10,11] New Pedagogies for Deep Learning (NPDL) Global Partnership initiative. In the NPDL project whitepaper Towards a New End: New Pedagogies for Deep Learning [10] (p. 5) the authors state, the partnership begins with the proposition that our education systems need new policies, measures, and evidence-based pedagogical models to enable learning relevant for the knowledge-based, globalized era.

There has been considerable research into the globalized agenda that has systematically reformed education policy and practice in many nations $[8,18-20]$ The evolution of the concept of the knowledge economy and the knowledge worker, introduced in A Nation at Risk (1983) with a call for the creation of a Learning Society are seen today in 21st century initiatives that are re-shaping education. It has been argued that neoliberalism, globalization, and the knowledge economy taken together as ideological constructs, "exert considerable shaping force on education systems ... to the point where it can be seen to be futile to argue that their effects may not constitute either educational or economic 
good." [20] (p. 1). Yet it is important to question the powerful presuppositions about neoliberal, technical, and rationalist influences on the larger aims and goals of education.

The preparation of knowledge workers and people who can thrive in the "knowledge-based and globalized era" [10] (p. 5) by attaining the necessary 21st century skills and competencies will be a driver of economic growth and improved competitiveness for nations seeking advantage under globalized market conditions. Fullan and Langworthy [11]) state unequivocally, "Productivity in the knowledge-based, value-creation-oriented global economy of the 21st century requires individuals who create new ideas, new products, new solutions and new content" (p. 34). In this sense, the transformation called for, when viewed through a critical lens, is anything but radical as the end of education is understood to be the creation of the knowledge worker.

\section{The Skills and Competencies: A Closer Look}

Twenty-first century education reports and agencies almost all agree on the four C's of 21st century learning: critical thinking, communication, collaboration, and creative problem solving [13]. To those four, Fullan and Langworthy [10] and the New Pedagogies for Deep Learning Global Partnership added character education, and citizenship; while others specifically included culture, and computer and digital technologies [21].

For much of the 1990s and the early 2000s, 21st century skills were virtually synonymous with computer and information communication technology (ICT) skills [22]. More recently, an international consensus has coalesced around the skills, competencies, knowledge, beliefs, and dispositions young people will need to thrive in the 21st century [9-16]. Ehrcke [8] has shown corporations, specifically technology companies, have been very active in promoting 21st century teaching and learning as they understand workplaces, present and future, require employees adept at systems and design thinking, collaboration, creative problem solving, communication, and logical reasoning. Corporations are interested in developing future employees who display risk-taking and resiliency, who are comfortable with ambiguity, and who embrace innovation and an entrepreneurial spirit. As 19th and 20th century companies inserted themselves into school systems to train the workforce they required for industry and manufacturing, Ehrcke [8] argues, so too, do corporations today allied with not-for-profit groups and governments, have vested interests in what happens in classrooms. Corporations are working to influence education reform. Silicon Valley billionaires are investing huge sums to establish private schools and experimental approaches to individualized, experiential education and personalized learning. Kuchler [23] (p. 6) writes, Silicon Valley is, as ever, optimistic. It wants to move on from a 19th century, artisanal model of education, where knowledge resides with each classroom teacher, to a personalized experience that technology can replicate on a global scale. The new model focuses on skills ... and social abilities that will be needed, whatever the workplace.

In 2015, the United Nations published Resolution 70/1 Transforming Our World: The 2030 Agenda for Sustainable Development. The seventeen Sustainable Development Goals (SDGs) and 169 targets call for deep commitment to 21st century competencies and a creativity-intense, technology enhanced re-design of the purposes and approaches to education. The goals and targets represent a "supremely ambitious and transformational vision" [24], (p. 7) and require all segments of civil society and stakeholders to re-imagine how to meet the challenges before us. This call by the United Nations also quickens the mission of 21st century learning.

Taken together, the initiatives and approaches described above characterize the global embrace of 21st century skills and competences and represent an important and powerful shift in education. Momentum is building as countries, states, provinces and school systems re-write curricular and learning goals to align with "deep learning and new pedagogies" [10] for 21st century skills and competencies. Intensive efforts are underway to re-design education systems to increase the scalability of new pedagogies and technology-enhanced learning by re-thinking leadership roles and creating enabling conditions for whole system change [11]. 
Next, I would like to open the concept of 21st century skills and competencies to engage with what is silenced in the discourse of deep learning and turn to the foundational question-21st century learning for what purpose? In a functional, future-oriented understanding of education [12] represented by 21 st century learning there are fundamental beliefs that betray deep value systems about the aims of education that are rarely articulated in the documents. However, these values require careful inquiry. Educators, private groups, corporations, consortiums, and governments have been proposing nothing less than a radical reforming of education [11] (p. 13). The word radical is not used lightly, and it provides a good starting point for further discussion.

\section{21st Century Learning as Radical Change}

The radical change proposed by promoters and advocates of 21st century skills adheres to the dictionary definition of the word, a "thorough or extreme change to traditional forms." [25]. But the word radical means something else and it is to the life of the word that we can look to recover a meaning with which it was once imbued. Words can lose their lived meaning through overuse and paying close attention can re-vitalize the language and connect us to the lived experience to which the word was originally tied. The word radical has heft; it is a word charged with the political and the subversive. Calling for radical change in education is done for effect. The word comes from the Late Latin radical-is and meant, "the direct source or sense" [26] (p. 428). It is a word rich in depth and nuance as it is related to "roots and rooting." In medieval philosophy, the radical humor was inherent in all plants and animals, its presence being a necessary condition of life. It is this sense of the word radical that I would like to invoke regarding education reform; it is the word's connection to the fundamental, primary, essential condition of life, that may help us respond to the question of, "radical change in education, for what purpose?" When the goals of education are aligned with an ethos of life and living, the fundamental question of what we are reforming education for, can be posed as a counterpoint to the functional, future-oriented, technology-enhanced belief in education for its neoliberal, economic, career, and problem solving purposes.

It is not my aim to disparage efforts to reform education for 21st century learning, but to understand more deeply its stated and implicit purposes. To understand more deeply necessitates a turn to the philosophical, specifically, to a tradition interested in describing life and the life world as it is actually lived-namely phenomenology. Also, as with most fundamental questions such as, what are the purposes of 21st century learning we are taking up an interpretive task that calls for hermeneutic reflection and a dialogical approach to engage with the language and thereby understand more deeply the value ground of the reforms.

Looking carefully at recent documents that espouse transforming education for the skills of 21st century learning provides a clearer sense of the demands placed on education. As indicated above, one recent international initiative represents many national and international programs that are often more similar in language and intent than different. The international project New Pedagogies for Deep Learning: A Global Partnership (NPDL), led by Canadian education consultant and scholar Michael Fullan, is well-funded and highly organized with partners that include multinational corporations like Intel, Microsoft, and Pearson Publishing. New Pedagogies for Deep Learning is working with "clusters" of a hundred schools in each of ten countries. The goal is to build collective capacity within and across education systems and "to call to action, engage partners in the common purpose to mobilize deep learning, capture and cultivate new pedagogies that advance deep learning, and continuously measure and analyze what is working" [10] (p. 19-20). The NPDL whitepaper Towards a New End: New Pedagogies for Deep Learning begins by describing a crisis in public education, namely student disengagement and teacher frustration. The document states, "education needs to be radically re-thought" [10] (p. 1). Fullan and Langworthy [10] explain the crisis in education is "intrinsic to our societies' transition to knowledge-based economies and global interdependency, enabled and accelerated by technology" (p. 1). The authors add, "Amid the challenges, we have begun defining the 
what: new goals for learning relevant to this new era. However, the immediate and expansive attempts to innovate the how; the process of education-are urgently required" (emphasis in original, p. 1).

While the "what" and "how" of education are the central concerns of the ambitious global initiative, the "why" is less well developed. Fullan and Langworthy $[10,11]$ (p. 2) attempt to address the "why," the larger purpose of the global education reform initiative by explaining the NPDL partnership, seeks to renew our goals for education and learning to include skills that prepare learners to be life-long, creative, connected problem solvers and to be happy, healthy individuals who can contribute to the common good in today's global interdependent world. We need learning systems to encourage youth to develop their own visions about what it means to flourish and equip them with the skills to pursue these visions.

On the surface this seems to be perfectly reasonable and common sense. Who would not want children to be happy, healthy, flourishing people equipped to be successful in a complex and changing world? Yet, a claim like this becomes problematic when framed in the language of crisis and in an apparent value-neutral way that leaves young people to "develop their own visions" about what it means to flourish and "contribute to the common good." In this way, the authors avoid the "why' of education for an instrumental, functional view of education tacitly related to "happiness, health and flourishing" but the larger vision is never fully elucidated. Instead Towards a New End: New Pedagogies for Deep Learning [10] reflects, as other similar documents do, a discourse connected to the establishment of the Learning Society (17), the Knowledge Economy and the preparation of people who can take their place and contribute to the new era characterized as a "a constantly emerging world" [10] (p. 2) by being fully committed to continuous life-long learning.

The absence of a discussion of the larger aims of education may indicate the unquestioned acceptance of the constructs of neoliberalism, globalization, and the knowledge economy. There is no need to engage with the "why" of education because it is a normative apriorism, a deep value system and moral syntax that govern beneath thought or evaluation. When education adapted to the demands of the global economy, learning and learners are commodified as knowledge and knowledge workers in the service of the economy or what McMurtry $[27,28]$ calls the market or money code of value. Guided by this value, education is to contribute to the neoliberal economic construct, generate personal wealth that in turn grows the economy through consumer spending in an infinite upward spiral of progress, growth, consumption and wealth (money) creation. Is it possible the deeper aims, goals or mention of big philosophical questions are avoided not by design, but because the ruling value system is presupposed as the final order of reality?

\section{A Critique of Learning}

Biesta $[29,30]$ has inquired into the emergence of the "learning age" or Learning Society called for in A Nation at Risk [17]. Biesta calls what happened in the 1980s and 1990s as the "learnification" of education discourse. During these years, the word education was supplanted by "teaching and learning", students became "learners", and adults became "adult learners." Teachers have become "facilitators of learning;" classrooms and schools became "learning environments" [30] (p. 62). It was also during the 1990s and early 2000s that 21st century skills became 21st century "learning." Also becoming popular at the same time was the term "competencies" that served as a more inclusive word than "skills," as competencies also encompass knowledge, habits and dispositions. While it is difficult to argue with the importance of learning and competence, the shift in language, according to Biesta, began to "monopolize the discourse about teaching" and can be understood as a "convergence toward a particular way of thinking and talking about teaching that we should be worried about" [30] (pp. 122-123).

In 21st century learning the learners are "grounded in purposeful learning by doing." [10] (p. 4). Yet, the learning is essentially neutral and lacking meaningful reference to content, direction and larger purpose. Fullan and Langworthy argue, "the new learning goals are a moral imperative" [10] (p. 7). The NPDL initiative is deeply committed to the power of learning, especially learning enhanced by new 
technologies and related technologies so that "participants are motivated to go deeper and do more. The Partnership's moral imperative will guide all our work: the pursuit of deep learning goals enabled by new pedagogies and accelerated by technology" [10] (pp. 7-8). Unfortunately, until the purpose of the deep learning is more lucidly articulated such pronouncements are generally empty of meaning. The "learning" is an end unto itself; learning is the "new end" that is referenced in the very title of the whitepaper. Learning is the moral imperative that makes it challenging to fully engage with the question-learning for what purpose that takes us beyond the narrow, technical, rationalist, functional, and preparatory vision of readying students to meet the needs of a globalized, knowledge economy.

As previously stated, it is not my intention to undermine the efforts underway to re-orient education for 21st century skills but to address and attempt to get behind the educational end in view of 21st century learning that is largely silenced in current discourse. In many respects 21 st century educational initiatives represent a moving away from traditional education approaches that are transmissive, controlling, authoritarian and demanding of compliance in behavior and thought. The attention on creativity and imagination, collaboration, and critical thinking is hopeful, as is the renewed emphasis on the importance of student-teacher relationships.

However, the virtual absence of a purpose for learning, and a failure to articulate that to which the learning points, is problematic. A functional bias toward preparation for the knowledge economy, a fear of being left behind in a competitive global race for economic dominance is betrayed in Fullan and Langworthy's language describing teachers as "human capital" who have "social capital (the relationships with students, parents and community)" and "decisional capital (negotiating the challenging learning experience)." [10] (p. 13), The language of "capital" has symbolic and rhetorical power. It speaks to the tacit purpose of education reform for 21st century learning-to protect and strengthen the social and economic status quo firmly anchored in a market based, competitive economic ideology. It is in this sense that the education transformation 21st century learning intends to represent it is not the radical rethinking of education it positions itself to be.

\section{Towards a New End for 21st Century Education}

Education for 21st century learning requires a deep engagement with the question of the larger purposes of education. One of most pressing existential questions for education that is generative and generational is how humans as a species will continue to live, and live well, and sustainably on this planet. Aligning transformational educational change with status quo, functional, economistic thinking is an ironic refutation of the critical thinking and deeper learning called for by new pedagogies and 21st century education. Orr [31] presents succinctly a purpose and vision for education in which the goal is not merely deeper 'learning' and new pedagogies but learning toward life and making connections. David Orr [31] (p. 138) writes of his vision for education, first, it aims toward the establishment of a community of life that includes future generations, male and female, rich and poor, and the natural world. The essence of community is recognition, indeed celebration, of interdependence between all parts. Its indicators are the requisite sustainability, peace, harmony and justice and participation.

Orr is advocating for a vision of education that is inclusive, encompassing, expansive, generous, life affirming and reaches toward a place of deep transformation. The discourse of 21st century learning is one in which there is confidence and power, a techno-optimistic, and future-facing resolve that education, or more aptly, learning, specifically deep learning will conserve a way of life founded on intensely held cultural beliefs about progress, growth, development, competition and technology. However, much has been written about the misplaced faith and confidence in technology and in unfettered growth and consumption that has given rise to the Anthropocene and the threat posed to all life on the planet $[28,32,33]$. Adhering to the belief that humans dedicated to the Western myth of infinite, linear progress have the wisdom to act in ways that are life affirming is neither radical nor transformative.

Education has not been a panacea for the world's ills; as education levels rise so too do the myriad issues related to unsustainable consumption and inequities in the distribution of wealth. 
Students will only "develop their own visions about what it means to connect and flourish" [10] (p. 2) when educators, researchers, policymakers, and all stakeholders deepen radically a sense of interconnectedness, earth-centeredness, and humility that are both accepting and mindful of the paradoxical relation of the flux, uncertainty, and unpredictability of life. There have been international efforts to reform education for an ethos of interconnectedness. Education for Sustainable Development (ESD) was born out of the Earth Summit in 1992, Chapter 36 of the Agenda 21 document presented a vision of the world's education systems educating in ways that would lead to a more sustainable future. Education for sustainable development has emerged as an approach to teaching and learning that is locally relevant, culturally appropriate, and addresses all realms of sustainability (environment, society, economy), however, ESD too has been a contested approach and critiqued for the co-optation of the terms sustainable and development by corporate interests [34]. Despite this, ESD promotes similar competencies as 21 st century learning $[35,36]$ however with the explicit vision, "to help communities and countries meet their sustainability goals and attend to the well-being of the planet and all its living inhabitants" [37] (p. 7).

\section{Money Code of Value versus Life Code of Value}

To help us think about an alternative "end" for 21st century education other than the functional, neoliberal tacit understanding that children and young people are being prepared for the realities of a global economy, I turn to the work of philosopher John McMurtry, who characterizes the dominant economic system that has fully been absorbed into culture, policy, government, education and our daily understanding of "reality," as a system that promotes money and the market above all else. McMurtry's research $[27,28,38,39]$ has focused on the value structure of economic theory and its influence on human rights and ecological well-being. McMurtry has published in diverse fields of inquiry including social and political philosophy, Asian/Indian and Chinese philosophy, Marxist theory and Deep Ecology. His concepts of the life code of value and money code value help us think more deeply about the ultimate ends of a 21st century education. The life code of value expresses what McMurtry calls the "life-ground" a comprehensive conception of the lifeworld located in the concrete experiences of people's lives and "keeps its eyes on life and its capabilities to think, feel or do, observing whether there is maintenance, growth or decline in these vital fields of being alive" [27] (p. 24).

McMurtry points to the concept of the life-code of value existing in ancient texts and cites the work of Chinese philosopher Wang Yang Ming writing 2500 years ago to demonstrate that humans have a "life code within us" and "this structure of concern for life beyond our skins is spontaneous to humanity, and it underlies even our most conditioned blindnesses" [27] (p. 368). McMurtry's concept of the life ground firmly rooted in human experience and the concrete everyday reality of people is informed by a phenomenological approach that makes an appeal to experience and is receptive and open to new interpretations that challenge abstract theoretical constructs and unexamined assumptions and structures. Phenomenology invites us to be open to the concreteness of the lived world-a world interpreted from within rather than through the lens of adopted categories and rationalizations. It is a common misconception to regard the phenomenological focus on the experiential and the human life world as an arbitrary, first person account of facts experienced by a lone subjectivity. Phenomenology challenges abstract generalized claims about the way the world is, but it equally avoids merely relativistic, first-person story-telling where just anything goes" [40] (p. 11). The demand of the life ground of which McMurtry writes can be discovered by "paying attention not only to our experience of nature, but the nature in our experience [41] (p. 26). An experiential approach to better understand the lived experience of the life ground and the life code of value is based on the organismic wisdom at work in our bodily felt experience and relies on what John Dewey [42] called "the directive powers" (p. x) that inhere in it.

McMurtry offers another way of thinking about the purpose of education. An understanding of his codes of value may have consequences for another vision for 21st century teaching and learning. 
Depending on which value orientation is chosen (whether consciously or unconsciously), the ends of 21st century education will be very different. McMurtry [27] describes the dominant market system as a value code "that underlies people's normal decisions and actions ... [and] is one that affirms more money revenues as good and rejects less money revenues as bad." (p. 297) He calls this apriori principle of value and disvalue the corporate value program or the money-code of value. It is represented simply as,

\section{Money $\longrightarrow$ Commodity for Sale $\longrightarrow$ More Money}

Money is the beginning and the end of the sequence. In opposition to the money code of value McMurtry $[27,28]$ proposes the life code of value. The life code of value is represented by the following sequence,

\section{Life $\longrightarrow$ Means of Life $\longrightarrow$ More Life}

McMurtry defines life as "organic movement, sentience, and feeling, and thought" [27] (p. 298). Means of life is "whatever enables life to be preserved or to extend its vital range on these three planes of being alive" (p. 298) such as clean air, water nutritious food, shelter, affective interaction, environmental space, and accessible learning conditions. Maintaining these conditions reproduces life; augmenting and deepening them increases life-value.

The codes of value-money and life-are different in that in the money code of value money is the beginning of the value sequence and money is the end of the sequence. "More money," says McMurtry [27] "and not more life is the regulating objective of thought and action" (p. 299). The more money that returns to the investor regardless of what happens to life, the better the investment. A money code of value shapes all aspects of schooling. When corporate interests permeate education discourse schools become merely job preparation centers educating for the technological skills and requirements of a 21 st century workplace.

To illustrate the difference in the money code and life code value systems I need only to turn on my radio. As I write, the news relates the story of angry protests outside the corporate headquarters of a large Canadian aerospace manufacturer. The company has been given a billion dollars of taxpayer money in the form of assistance in the past two years. As well, the corporation has laid off thousands of employees with plans of eliminating more than 14,000 jobs around the world. Yet, the senior executives of the company were set to award themselves millions of dollars in compensation and bonuses. The public was outraged [43]. However, according to the money code of value underpinning corporate culture, policy, and decision making, what the executives were about to do is to be expected and is perfectly acceptable. It is logical, rational, and good according to the money code of value. The company executives could maximize shareholder investment (money) by leveraging a billion dollars of public money while stripping thousands of their employees and their families of their livelihoods. As McMurtry reminds us, according to the money code of value, more money is always good, regardless what happens to life. So deeply governed are the executives by this value that they were ready to accept their rewards blind to the moral outrage of people who were asserting different values-namely, life code values. It is only when the more extreme instances of the money code of value sometimes push through as when pharmaceutical companies make life saving medication inaccessible by grossly inflating the price does the money code of value emerge and sometimes becomes visible above the deep stratum and fundamentalist inner logic that guides all decision making and thought processes.

Life values are beginning to re-assert themselves and it is these values that must guide discussions of 21st century education. McMurtry's life code of value offers a theoretical construct for an alternative value system with which most people are already familiar. It manifests itself in people's lives everyday as the civil commons. McMurtry recognizes the civil commons as "any cooperative human construct that enables the access of all members of a community to life goods" [27] (p. 371). The civil commons are what people ensure together to protect as distinct from the money code of value logic. Universal 
health care, parks, green spaces, volunteer service groups, fire protection, clean water, food inspection, good government, a justice system, libraries and public education are all examples of what many believe are life-based and life-protective. These are, as part of the civil commons, oriented to life values, not money values. Commodifying any of these or attempts to turn them over to market based, private, for profit entities are met with great debate and resistance from many people. These are all life affirmative forms of capacity building and allow society to protect and enable open access to life goods or the means to life.

These are values built on human agency and enable access for all community members not just a privileged few to grow and express themselves. The community may be local, national or global. In a life code value, education is a life good, both public and individual, and is not a commodity. Children and young people are not commodified learners, knowledge workers, consumers, or human capital. Children are on the path of human "becoming." They are in need of pedagogical relationships with teachers entrusted to lead them in search of meaningful lives and the beauty of their full potential as flourishing individuals.

\section{Creativity and the Life Process}

There is much in 21st century education that when understood through a life code of value shifts the regulating principles and the moral imperatives of education in more expansive and life- affirming directions. If we look at one goal of 21st century learning to develop in the young an increased capacity for creativity and innovation, we understand it differently through an alternative lens. Creativity, inquiry, experimentation, collaboration problem solving, and innovation are at the heart of 21st century learning. Fullan and Langworthy [11] write, "Today our economies are shifting, and the new models are ones of learning and innovation, of entrepreneurship, of creativity, and of global collaboration" (p. 4). Creativity is generative. The word has roots in Latin meaning "to make or produce," or "to grow" [26] (p. 144). Like the word radical, the word creative is inextricably tied to the life process. Creativity relies on tenuous experimentation, and imagination. It develops with patient uncertainty and often arises mysteriously when least expected. Creativity cannot be summoned forth, or forced, but emerges when the conditions and the context are supportive and nurturing.

When education is seen to be in the service of life and a life code of value it speaks to larger purposes that touch all we do in teaching or leading out the next generation. Twenty-first century learning approaches take on new meaning and vitality when allied with a life-affirming ethos and purpose. Twenty-first century education is inherently experiential and working experientially offers a way to formulate alternative interpretations of reality, interpretations based on our felt contact with the world, and can challenge taken for granted historical and cultural beliefs or the existing neoliberal, instrumental reality principle. Twenty-first century learning is interactive and dialogic. Building an experiential sense and involvement in the community of life develops awareness of how we are connected, interdependent, and intertwined, undoing an individualistic, competitive, isolating feel for the world. The experiential pedagogies of 21st century learning when aligned with a larger purpose as reflected in the life process, give authority to our experience. Student emotional and physical well-being can be supported through the open sharing of experience and moving forward toward actions that are for the life process, rather than against it. According to Fisher [41] (p. 27), experiential approaches avoid being dogmatic about what people must or ought to do. They do, however, maintain that our bodily experience of the world implies certain social changes and encourages us to take actions to move in the direction of those changes.

Education in the service of life has as its fundamental goal the life forwarding steps that emerge from making authentic contact with the world. This approach takes advantage of the creativity inherent in the life process, of the uncertainty, the new meanings and possibilities that arise with the unfolding of experience. As we approach the end of the second decade in the 21st century, schools are required to respond to myriad issues related to the physical and emotional health of children and youth. Some researchers estimate a mental health issue affects twenty-five percent 
of young people [44]. High levels of anxiety, increased prescribing of medications in the face of rising diagnoses of emotional, physical, and cognitive health issues as well as difficulties related to social disconnection and problematic uses of technology and social media are an everyday reality for teachers and administrators internationally. Ecopsychologists, environmental and sustainability educators, and curriculum theorists have written a great deal about the unfolding of human life as a phenomenon of nature and share insights for connecting children's lives with the experience of cultural and ecological diversity and the role these play in the life forwarding development of children and youth [41,45-48].

\section{Conclusions}

Deep learning that is transformative and designed to take students forward into the next century requires a larger vision than the one currently on offer. Education that has at its core, a reverence for the life process, rejects the maintenance of a functional, preparatory, largely instrumental and economic vision for a vision that fosters experiential approaches characterized by authentic contact and dialogue with the world. The "new end" and "new pedagogies" called for in 21st century learning require a re-acquaintance with long held truths, life values and wisdom traditions that have allowed humans to flourish and indigenous societies to thrive for millennia. This is not to take a romantic view of all such traditions, but to re-connect with those traditions that respond to what our contemporary experience is calling for. Experiential approaches allow for a high degree of flexibility by acknowledging the uniqueness of people's life situations. Experiential approaches avoid being dogmatic about what people ought to do and take advantage of the creativity of the life process. Twenty first century education must be predicated on living with children and young people through an experiential curriculum that is generative and life forwarding. It is education that enables students and teachers to be fully engaged in a way that enhances well-being for all members of the community of life.

From a hermeneutic perspective, the discourse of 21st learning works well as a technical, pragmatic interpretation of the larger purposes of education that reflect a neoliberal commodification of learners who must be prepared for a globalized, knowledge economy. The end in view is a well-prepared 21st century workforce of creative, innovative, entrepreneurial problem solvers able to contribute to the good of society. But in the dominant value system, the good is aligned with a money code of value. As technical, pragmatic, instrumental criteria, this educational vision makes perfect sense. However, the ends of education that are economic in nature are pre-given and represent a deep value system and moral imperative, so the radical re-thinking of education called for means finding an efficient way to meet these pre-determined ends. The instrumental rationality represented by the 21st century education documents cannot provide the larger purpose or vision of education, but rather they conserve the status quo. The unfortunate use of the term human capital [10] to describe teachers is characteristic of a de-personalized, de-humanized concern, as people are means to an identifiable end.

Instrumental rationalism that is concerned primarily with means and not ends should be tempered by ethics, practical wisdom and morality. While 21st century learning may make perfect sense as an efficient strategy to meet the pre-given end of strengthening a globalized, knowledge economy and providing a highly-qualified workforce for the future, it can be ethically, morally, historically and culturally invalid if its aim is to simply recreate the hyper-consumptive patterns of beliefs and behaviors that threaten the viability of life on the planet through a transnational globalization guided by a money code of value. By not engaging meaningfully with the end of education, proponents of 21st century learning miss the opportunity to open doors to rational debate, communication, mediation and resolution between education stakeholders with diverse knowledge, values and beliefs.

When the current final order of reality is shaped by a deep value system that governs mind-sets and firmly held belief systems, educators who espouse alternative values may despair that change is possible. But radical change is possible, and it is to the word radical we can turn a last time to call forth its connection with rooting, growth and development- that which emerges from the ground. Teachers in classrooms and principals responsible for organizing schools can make pedagogical choices 
every day to reflect life-code values. Educators who are awake to and aware of a different way, another vision for education predicated on human becoming can have enormous influence on engendering humane, life-forwarding approaches to education.

When education is based on the theoretical construct of life values, when life is central to the educational enterprise, we honor our embodied interaction in the world. Learning and creativity are generative and when see education through the lens of life values we come to know what we truly need as human beings to reach our full potential. Organizing the education of the young based on life forwarding principles grounded in the world - the social world, the human built world, and the natural world can foster contact and dialogue with the world and in so doing schools become Living Schools that organize learning in ways to enhance well-being for all, sustainably.

Funding: This research received no external funding.

Conflicts of Interest: The author declares no conflict of interest.

\section{References}

1. Bolstad, R.; Gilbert, J.; McDowall, S.; Bull, A.; Boyd, S.; Hipkins, R. Supporting Future-Oriented Learning and Teaching: A New Zealand Perspective (Ministry of Education). Available online: http://www. educationcounts.govt.nz/publications/schooling/109306 (accessed on 11 June 2018).

2. European Commission. Competence Frameworks: The European Approach to Teach and Learn 21st Century Skill. Available online: https:/ / ec.europa.eu/jrc/en/news/competence-frameworks-european-approachteach-and-learn-21st-century-skills (accessed on 30 May 2018).

3. Wagner, T.; Dintersmith, T. Most Likely to Succeed: Preparing our Kids for the Innovation Era; Scribner: New York, NY, USA, 2015.

4. Gibb, N. What Is a Good Education in the 21st Century? Available online: https://www.gov.uk/ government/speeches/what-is-a-good-education-in-the-21st-century (accessed on 1 June 2018).

5. Department of Education Nova Scotia. Renew, Refocus, Rebuild: Nova Scotia's Action Plan for Education. Available online: https: / / www.ednet.ns.ca/ education-actionplan (accessed on 20 June 2018).

6. Ontario Ministry of Education. 21st Century Competencies. Toward Defining 21st Century Competencies for Ontario. Available online: http://www.edugains.ca/resources21CL/About21stCentury/21CL_ 21stCenturyCompetencies.pdf (accessed on 30 May 2018).

7. Alberta Education. Framework for Student Learning: Competencies for Engaged Thinkers and Ethical Citizens with an Entrepreneurial Spirit. Available online: https:/ / open.alberta.ca/publications / 9780778596479 (accessed on 23 August 2017).

8. $\quad$ Ehrcke, T. 21st century learning Inc. Our Sch. Our Selves 2013, 22, 61-81.

9. Ananiadou, K.; Claro, M. 21st Century Skills and Competences for New Millennium Learners in OECD Countries. Available online: http:/ / dx.doi.org/10.1787/218525261154 (accessed on 11 June 2018).

10. Fullan, M.; Langworthy, M. Towards a New End: New Pedagogies for Deep Learning. Available online: http:/ / www.newpedagogies.nl/images/towards_a_new_end.pdf (accessed on 30 May 2018).

11. Fullan, M.; Langworthy, M. A Rich Seam: How New Pedagogies Find Deep Learning. Available online: http://www.michaelfullan.ca/wp-content/uploads/2014/01/3897.Rich_Seam_web.pdf (accessed on 30 May 2018).

12. Brooks, M.; Holmes, B. Equinox Blueprint: Learning 2030. Available online: http://www.wgsi.org/sites/ wgsi-live.pi.local/ files/Learning\%202030\%20Equinox\%20Blueprint.pdf (accessed on 20 June 2018).

13. P21. Partnership for 21st Century Learning. Available online: http:/ / www.p21.org/ (accessed on 30 May 2018).

14. C21. Canadians for 21st Century Learning and Innovation. Available online: www.c21canada.org (accessed on 1 June 2018).

15. OECD. 21st Century Learning: Research, Innovation and Policy. Available online: http://www.oecd.org/ site/educeri21st/40554299.pdf (accessed on 28 May 2018).

16. E21C. Education for the 21st Century. Available online: //www.e21c.co.uk/about-us/welcome/ (accessed on 30 May 2018).

17. National Commission on Excellence in Education. A Nation at Risk: The Moral Imperative of Educational Reform. Available online: https://www2.ed.gov/pubs/NatAtRisk/index.html (accessed on 10 May 2018). 
18. Olssen, M.; Peters, M. Neoliberalism, higher education and the knowledge: From free market to knowledge capitalism. J. Educ. Policy 2005, 3, 313-345. [CrossRef]

19. Davies, B.; Bansel, P. Neoliberalism and education. Int. J. Qual. Stud. Educ. 2007, 3, 247-259. [CrossRef]

20. Patrick, F. Neoliberalism, the knowledge economy, and the learner: Challenging the inevitability of the commodified self as an outcome of education. ISRN Educ. 2013. [CrossRef]

21. Jenkins, H. Confronting the Challenge of Participatory Culture: Media Education for the 21st Century. Available online: https://www.macfound.org/media/article_pdfs/JENKINS_WHITE_PAPER. PDF (accessed on 1 June 2018).

22. Jenson, J.; Taylor, N.; Fisher, S. Critical Review and Analysis of the Issue of "Skills, Technology and Learning". Available online: http:/ / www.edu.gov.on.ca/eng/research/Jenson_ReportEng.pdf (accessed on 1 June 2018).

23. Kuchler, H. Inside Silicon Valley's Classrooms of the Future. (Financial Times 2017). Available online: https:/ / www.ft.com/content/d629e512-e805-11e6-967b-c88452263daf (accessed on 1 June 2018).

24. United Nations. Transforming Our World: The 2030 Agenda for Sustainable Development. Available online: https:/ / sustainabledevelopment.un.org/post2015/transformingourworld (accessed on 2 June 2018).

25. Oxford University Press. Oxford English Dictionary; Oxford University Press: Oxford, UK, 2013.

26. Ayto, J. Bloomsbury Dictionary of Word Origins; Bloomsbury: London, UK, 1990.

27. McMurtry, J. Unequal Freedoms: The Global Market as an Ethical System; Garamond Press: Toronto, CA, USA, 1998.

28. McMurtry, J. Value Wars: The Global Market Versus the Life Economy; Pluto Press: Sterling, VA, USA, 2002.

29. Biesta, G. Giving teaching back to education: Responding to the disappearance of the teacher. Phenomenol. Pract. 2012, 6, 35-49.

30. Biesta, G. The Beautiful Risk of Education; Paradigm: London, UK, 2013.

31. Orr, D. Ecological Literacy: Education and the Transition to a Postmodern World; SUNY Press: Albany, NY, USA, 1992.

32. O'Sullivan, E. Transformative Learning: Educational Vision for the 21st Century; Zed Books: London, UK, 1999.

33. Huesemann, M.; Huesemann, J. Techno-fix: Why Technology Won't Save Us or the Environment; New Society Publishers: Gabriola Island, BC, USA, 2011.

34. Jickling, R.; Sterling, S. (Eds.) Post-Sustainability and Environmental Education: Remaking Education for the Future; Palgrave MacMillan: New York, NY, USA, 2017.

35. United Nations Economic Commission for Europe. Learning for the Future: Competences in Education for Sustainable Development. Available online: https:/ / www.unece.org/fileadmin/DAM/env/esd/ESD_ Publications/Competences_Publication.pdf (accessed on 2 June 2018).

36. Council of Ministers of Education Canada. Background-Developing a Pan-Canadian Framework for Collaboration and Action. Available online: http://www.cmec.ca/Publications/Lists/Publications/ Attachments/222/ESD-collaboration-action.pdf (accessed on 12 June 2018).

37. McKeown, R.; Nolet, V. Education for sustainable development in Canada and the United States. In Schooling for Sustainable Development in Canada and the United States; McKeown, R., Nolet, V., Eds.; Springer: New York, NY, USA, 2013; pp. 3-22.

38. McMurtry, J. Human rights versus corporate rights. Life value, the civil commons and social justice. Stud. Soc. Justice 2011, 5, 11-61. [CrossRef]

39. McMurtry, J. The Productive Base as the Ground of Society and History. Marx's Base Super-Structure Theory. Available online: https: / www.globalresearch.ca/the-productive-base-as-the-ground-of-societyand-history-marxs-base-superstructure-theory/5623772 (accessed on 1 June 2018).

40. Stefanovic, I. Safeguarding Our Common Future: Rethinking Sustainable Development; SUNY Press: Albany, NY, USA, 2000.

41. Fisher, A. Radical Eco-Psychology: Psychology in the Service of Life; SUNY Press: Albany, NY, USA, 2002.

42. Dewey, J. Experience and Nature, 2nd ed.; Dover: New York, NY, USA, 1958.

43. Peritz, I. Bombardier Delays Most Executive Pay Hikes Amid Rise in Public Anger. (The Globe and Mail). Available online: https:/ /www.theglobeandmail.com/report-on-business/hundreds-rally-againstbombardier-pay-hikes-in-montreal/article34557782/ (accessed on 30 May 2018).

44. Rodger, S.; Hibbert, K.; Leschied, A.; Pickel, L.; Atkins, M.; Stepien, M. Mental Health Education in Canada: Teacher Education Literature Review. Available online: https:/ phecanada.ca/sites/default/files/content/ docs/resources/teachereducationliteraturereview.pdf (accessed on 1 June 2018). 
45. Orr, D. Earth in Mind: on Education, Environment and the Human Prospect; Island Press: Washington, DC, USA, 1994.

46. Jardine, D. To Dwell with a Boundless Heart: Essays in Curriculum Theory, Hermeneutics, and the Ecological Imagination; Peter Lang: New York, NY, USA, 1998.

47. Gruenewald, D.; Smith, G. Place-Based Education in the Global Age: Local Diversity; Lawrence Erlbaum: New York, NY, USA, 2008.

48. Hensley, N. Curriculum Studies Gone Wild: Bioregional Education and Scholarship of Sustainability; Peter Lang: New York, NY, USA, 2011.

(C) 2018 by the author. Licensee MDPI, Basel, Switzerland. This article is an open access article distributed under the terms and conditions of the Creative Commons Attribution (CC BY) license (http:/ / creativecommons.org/licenses/by/4.0/). 